\title{
The Early Childhood Behavior Questionnaire Very Short Form (ECBQ VSF) and its adaptation to the population of the Czech Republic
} Kwestionariusz Zachowań Małego Dziecka - Wersja Bardzo Krótka (ECBQ VSF) i jego czeska adaptacja

\author{
'Department of Christian Education, Sts. Cyril and Methodius Faculty of Theology, Palacký University Olomouc, Olomouc, Czech Republic \\ ${ }^{2}$ Institute of Special Pedagogy Studies, Faculty of Education, Palacký University Olomouc, Olomouc, Czech Republic \\ Correspondence: Doc. PhDr. \& Mgr. Petra Potměšilová, PhD, Cyrilometodějská teologická fakulta UP, Univerzitní 22, 77100 Olomouc, (Zech Republic, tel.: +420 585697167 (111), +420 603293252 , \\ e-mail: petra.potmesilova@upol.cz
}

\begin{abstract}
Temperament can be defined as a complex of typical innate traits which manifest themselves in characteristic ways of reacting, acting, and feeling. In 1981, Mary Rothbart published the Early Childhood Behavior Questionnaire on toddlers' behaviour, based on parental assessments in certain situations, which perceived temperament as "constitutionally-based individual differences in reactivity and regulation." The process of adapting the tool to the Czech population commenced in 2017. Objectives: The aim of the study was to adapt the Early Childhood Behavior Questionnaire Very Short Form (ECBQ VSF) on temperament to the Czech population of children. The results are to be used for the possible distribution to child psychologists for research purposes. Subjects and setting: The data were obtained from a representative sample of parents of 709 children aged 18-36 months [371 (52\%) boys and 338 (48\%) girls]. Results: The reliability of the adapted test was verified with Cronbach's alpha - first, for individual scales in general, then for individual scales divided by gender and age. Except for one case (boys - Surgency scale - age 18-23 months), Cronbach alpha values were within an acceptable range. The distribution of items into individual scales was verified with a factor analysis. The factor analysis confirmed the distribution of items into scales with the similarity of the original questionnaire's version. Five controversial items were identified. Future research activities will focus on explaining this phenomenon. Differences between values obtained in boys and girls were determined with two-way ANOVA. The differences were found in the Surgency scale according to age and the Effortful Control scale according to age and gender as well. In the Surgency scale, the score increases along with the age; with the Effortful Control scale, girls achieved higher scores than boys. The score also increases with probands' age. Upon the completion of the work, the ECBQ VSF questionnaire was adapted for the use in research activities targeted at the Czech population. Study limits: The results are based on a parental evaluation, but this was entirely consistent with the process of the creation of the original tool.
\end{abstract}

Keywords: temperament, ECBQ questionnaire, adaptation, Czech population

Streszczenie Temperament można zdefiniować jako zbiór wrodzonych cech - typowych dla danej osoby - które przejawiają się w charakterystycznych sposobach reagowania, działania i odczuwania. W 1981 roku Mary Rothbart opublikowała Kwestionariusz Zachowań Małego Dziecka (Early Childhood Behavior Questionnaire) oparty na ocenach rodzicielskich uzyskanych w pewnych sytuacjach. Zgodnie z tym kwestionariuszem temperament to „wrodzone indywidualne różnice w reaktywności i regulacji”. Proces dostosowywania omawianego narzędzia do populacji czeskiej rozpoczęto w 2017 roku. Cele: Celem badania była adaptacja Kwestionariusza Zachowań Małego Dziecka (Early Childhood Behavior Questionnaire Very Short Form, ECBQ VSF) dotyczącego temperamentu do czeskiej populacji dzieci, co pozwoliłoby na ewentualną dystrybucję narzędzia wśród psychologów dziecięcych w celach badawczych. Osoby badane i procedura: Dane uzyskano od reprezentatywnej próby rodziców 709 dzieci w wieku 18-36 miesięcy [371 (52\%) chłopców i 338 (48\%) dziewcząt]. Wyniki: Rzetelność kwestionariusza zweryfikowano za pomocą współczynnika alfa Cronbacha - w pierwszej kolejności dla poszczególnych skal ogólnie, a następnie dla poszczególnych skal według płci i wieku. Z wyjątkiem jednego przypadku (chłopcy - skala Surgencji - wiek 18-23 miesiące) wartości współczynnika alfa Cronbacha mieściły się w dopuszczalnym zakresie. Dystrybucja cech do poszczególnych skal została zweryfikowana za pomocą analizy czynnikowej. Analiza czynnikowa potwierdziła podział cech na skale z zachowaniem podobieństwa do oryginalnej wersji kwestionariusza. 
Wyróżniono pięć kontrowersyjnych pozycji. Przyszłe działania badawcze skupią się na wyjaśnieniu tego zjawiska. Różnice między wartościami uzyskanymi u chłopców i dziewcząt określono za pomocą dwuczynnikowej analizy wariancji ANOVA. W skali Surgencji ujawniono różnice według wieku, a w skali Samokontroli - w zależności od wieku i płci. W skali Surgencji wynik wzrasta proporcjonalnie do wieku; w skali Samokontroli dziewczęta osiągały wyższe wyniki niż chłopcy. Ponadto wynik wzrasta proporcjonalnie wraz z wiekiem badanych dzieci. Efektem prac była adaptacja kwestionariusza ECBQ VSF, umożliwiająca jego wykorzystanie w badaniach prowadzonych w populacji czeskiej. Ograniczenia: Wyniki opierają się na ocenie rodziców, niemniej było to całkowicie zgodne z procesem tworzenia oryginalnego narzędzia.

Słowa kluczowe: temperament, Kwestionariusz Zachowań Małego Dziecka (ECBQ), adaptacja, populacja Republiki Czeskiej

\section{INTRODUCTION TO THE ISSUE}

$\mathrm{I}$ n accordance with Kagan (1989), temperament can be defined as the innate patterns of the biological functions of an organism, and patterns of behaviour. These patterns are innate and observable, depending on an individual's personal experience.

Temperament is involved in creating individual differences in the regulation and modulation of emotions, attention, behaviour, and motor skills (Gartstein and Rothbart, 2003; Rothbart, 2007). These patterns are demonstrated from birth and are observable, depending on the individual's personal experience (Kagan, 1989). Blatný (2010, p. 15) sees the term "temperament" as relating to the psychological characteristics of the personality that is innate. A biological basis for these can be identified, as they relate to the formal side of behaviour and feelings. Buss (1991) describes three basic characteristics of temperament: it emerges during the first year of life, continues to maintain its main traits in adulthood, and is hereditary. Blatný (2010) states that despite agreement on the term "temperament," one substantial difference exists between the definitions, i.e. whether emotional personality traits are considered temperament (e.g. Allport) or only formal aspects of behaviour (e.g. Buss). To summarise, the concept of temperament is the individually characteristic way a person reacts, behaves, feels, and acts in reaction to interior and exterior impulses. Rubin et al. (2017) and Ullsperger et al. (2016) pointed out that the developmental role of temperament has mostly been studied with respect to the socioemotional domain, where it has been associated with both externalising and internalising problems. The relationship between temperament and social competencies is mentioned, for example, by Baer et al. (2015) and Penela et al. (2015). Rothbart and Hwang (2005), who created the tools described below, perceive temperament as an innate individual dissimilarity that manifests itself even before higher cognitive and social aspects of personality development. They also define temperament as individual differences in reactivity and self-regulation expressed in the areas of emotions, activity, and attention.

The modern concept of temperament based on the synthesis of most commonly used concepts characterising temperament - such as genetic and biological - brought Shiner
“Temperament traits are early emerging basic dispositions in the domains of activity, affectivity, attention, and self-regulation, and these dispositions are the product of complex interactions among genetic, biological, and environmental factors across time" (p. 437).

The use of the Early Childhood Behavior Questionnaire (ECBQ) allows the concept of the definition of temperament to be extended to reactive processes involving not only emotions but also the functioning of the motor and sensory system. The questionnaire also contains items that reflect self-regulation processes and their influence on the formation of reactivity (Rothbart et al., 2001).

\section{Description of the instrument}

Rothbart and her team have so far created six instruments to measure temperament. These tools are divided by the age of the target group, such as the Infant (IBQ and IBQ-R), the Early Childhood (ECBQ), the Children's Behaviour Questionnaire (CBQ), the Temperament in Middle Childhood Questionnaire (TMCQ), the Early Adolescent Temperament Questionnaire (EATQ-R), and the Adult Temperament Questionnaire (ATQ). All the instruments have gradually been adjusted for the Czech population (Potměšil and Potměšilová, 2017).

This paper addresses the adaptation of one of the questionnaires, i.e. the Early Childhood Behavior Questionnaire Very Short Form (ECBQ VSF). The first reference (Goldsmith, 1996) to a questionnaire which assessed toddlers' temperament was created in 1996. This questionnaire has had undergone several revisions. The current form, in three versions - Standard ECBQ - which can be treated as a base - is a questionnaire for toddlers aged 18-36 months [Early Childhood Behavior Questionnaire; Putnam et al. (2006)] and is focused on assessing temperament in the toddler age group. The ECBQ is a validated 201item parental report measure of temperament in toddlers. There are also Short (107 items; 18 scales - Activity Level/Energy, Attentional Focusing, Attentional Shifting, Cuddliness, Discomfort, Fear, Frustration, High-intensity Pleasure, Impulsivity, Inhibitory Control, Low-intensity Pleasure, Motor Activation, Perceptual Sensitivity, Positive Anticipation, Sadness, Shyness, Sociability, and Soothability) and Very Short versions (36 items; three scales - Effortful Control, Surgency, and Negativity) (Rothbart, 2009). 
The ECBQ VSF, the 36-item very short form of this measure, was created to provide a broad overview of temperament among toddlers $18-36$ months. It was designed to measure the three main dimensions of child temperament: Surgency, Negativity, and Effortful Control. The ECBQ VSF is a 36 -item measure of toddler temperament that was developed in 2009 as an abbreviated form of the validated 201-item ECBQ (Putnam et al., 2006). The ECBQ VSF was developed to provide researchers with an efficient method for assessing the three pilot dimensions of temperament: Surgency/Extraversion, Negative Affectivity, and Effortful Control. Parents are asked to read questions about specific child behaviors and respond with the frequency with which their children behave in that way on a scale of 1 (Never) to 7 (Always), with the eighth option, "Does not apply," if that item is not relevant for their child.

The ECBQ VSF was translated into the Czech language by the present authors; it was successfully standardised, and the results are described below.

\section{AIM OF THE STUDY}

The present study aims to describe the process of adapting the very short form of the ECBQ to the Czech population, thus making it available to authorised experts.

The main objective was to answer the following questions:

- whether the adapted version is also valid for the Czech population;

- whether the same scales will apply in the adapted version;

- whether these scales will consist of the same items;

- whether there are differences in mean values between boys and girls.

Other goals of the study, apart from the above-mentioned research goal, were to obtain a functional tool for possible distribution to child psychologists and to create a tool for working with the parents of children with health or developmental risks. We also received feedback from parents who filled in the questionnaire during the main research, stating that they welcomed the "instructions" on how to observe their child and for what and where to seek possibilities for activation and stimulation.

\section{MATERIAL AND METHODS}

The adaptation of the EBCQ VSF questionnaire to the Czech population complied with the Standards for Educational and Psychological Testing (2014). The process was split into six basic stages. The first involved obtaining the questionnaire's authors' consent to its adaptation. Translation into Czech followed, performed by an independent translation agency. Next, it was sent to five psychologists who were fluent in English for their comments on the Czech version. These helped create a more intelligible and unambiguous text. In the second stage, the questionnaire was distributed to 15 volunteers for their opinions on the intelligibility and clarity of the individual items for potential modification. During this stage no substantial comments were made; the respondents complained about there being too many items in the longer versions; we, therefore, used the Very Short or Short forms afterward. The third stage involved a back-translation into English, again by an independent translation agency, followed by an authorial review. The fourth stage was a long and significant discussion with the authors of the original questionnaire regarding the "cultural adaptation" of some items and whether this did not change the questionnaire itself. The discussion was about different concepts of some items in the Czech Republic and the US. The outcome led to consensus on cultural adaptation while maintaining the consistency of the questionnaire. The fifth stage involved a pilot study. The questionnaire was sent to a group of volunteers, thus executing a feasibility study. If no comments emerged, the sixth stage was approached, i.e. the actual data collection.

\section{Selection of parent respondents}

With regard to the research objective, which was an adaptation of the questionnaire to the Czech population, a stratified selection of respondents was used, which allows random selection to select a certain number of respondents in the given subgroups, in this case in the given age categories. Parents from across the Czech Republic were addressed through social networks (parents from different parent groups), then questionnaires were placed in paediatricians' waiting rooms. The main criteria for choosing a respondent were:

- being a parent;

- having a child aged 18-36 months;

- the child not being disabled.

During the period 2017/2018, the data was obtained from a sample of parents (in all cases mothers) of 709 children aged 18-36 months [371 (52\%) boys and 338 (48\%) girls]. Of the total number of 709 questionnaires, 30 were submitted in a paper form, while the others were filled in via a Google version of the form. All the questionnaires were filled in by the parents (mainly mothers) working alone, without the intervention of the researcher. The collection was completed when the necessary number of children in each age group was reached. During the entire data collection, we received only three negative responses - refusal to complete the questionnaire for the sake of not wanting to indicate the date of birth of the child. This data was perceived by three mothers as sensitive. Demographic data such as social status, education, or housing - were not identified in this research.

The data was collected via paper and electronic questionnaires and copied into Microsoft Excel spreadsheets.

\section{Age and sex}

The statistical processing included a total of $N=709$ described children aged $18-36$ months, 371 boys (52\%) and 338 girls (48\%). As with the original questionnaire, three age categories (see Tab. 1) were created. 


\begin{tabular}{|c|c|c|c|}
\hline Age in months & Boys & Girls & Total \\
\hline $18-23$ & $131(35 \%)$ & $119(35 \%)$ & $250(35 \%)$ \\
\hline $24-30$ & $132(36 \%)$ & $137(41 \%)$ & $269(38 \%)$ \\
\hline $31-36$ & $108(29 \%)$ & $82(24 \%)$ & $190(27 \%)$ \\
\hline Total & $\mathbf{3 7 1 ( 1 0 0 \% )}$ & $\mathbf{3 3 8 ( 1 0 0 \% )}$ & $\mathbf{7 0 9 ( 1 0 0 \% )}$ \\
\hline
\end{tabular}

Tab. 1. Division of target groups of children by gender and age

As stated above, the goal was not to acquire a group of children with a normal distribution, but a group of children in which each age group would be represented by approximately the same number.

This assumption was confirmed from the data in Tab. 2. For boys and girls, we cannot confirm normal distribution. The standard deviation indicates that the number of children selected is spread over the entire width of the file. Furthermore, the mean values (mean and median) show that the number of children is balanced in the file.

\section{RESULTS}

Descriptive statistics were created first. In accordance with the research, reliability in relation to the original questionnaires was verified by Cronbach's alpha. Additional factor analysis was performed which enabled the verification of the division of the items into scales. Additionally, the lowest, highest, and median values were counted for the individual age categories and scales, and the upper and lower quartiles were determined.

\section{Reliability}

In accordance with the data published in scholarly journals (Gartstein and Rothbart, 2003; Klein et al., 2009; Putnam et al., 2006, 2014), the reliability of the adapted questionnaire was verified by calculating the Cronbach's alpha, first for the entire target group of children, then separately for the entire sample of boys and girls and for the individual genders and age groups.

In the study, Cronbach's alpha values $>0.6$ are considered acceptable and values $>0.7$ are considered good. The values for the research presented here are considered acceptable. The Cronbach's alpha (see Tab. 3) values for all respondents were within the acceptable range. Those amongst the boys lay within the acceptable to good range. The value is only low on the Surgency scale in boys aged 18-23 months. The values amongst the girls ranged from acceptable to good.

\section{Factor analysis}

The factor analysis was also performed. The first step was to determine the data's suitability for the factor analysis. We counted the value of Kaiser-Meyer-Olkin, $\mathrm{KMO}=0.76$ $(p<0.01)$ and an "anti-image matrix" was created, where the Measures of Sampling Adequacy (MSA) values were higher than 0.5 for all items; more precisely, they ranged from 0.6 to 0.85 . The last step included determining commonality, i.e. the level of correlation of an item with other items entering the factor analysis. The values of commonality for all items ranged from 0.5 to 0.73 .

The data provided above proves the data is suitable for factor analysis. The KMO value showed the average suitability of the data for factor analysis. The next values, MSA and communality, confirmed the suitability of the items for factor analysis. We extracted three factors which explained almost half the scatter in the items. The factors that were extracted (Tab. 4) corresponded to the three scales in the original questionnaire. The principal component analysis method was used to extract the factors and the number of factors was chosen on the basis of the Kaiser rule.

For easier interpretability, the factors were rotated by the Varimax method.

\section{Average values}

Reflecting the original version, the average values (see Tab. 5) of the individual scales were counted separately for the boys and girls.

\section{Age and gender}

The two-way ANOVA compares the mean differences between groups that have been split into two independent variables (factors) in our case: gender (2 groups) and age (3 groups).

\begin{tabular}{|c|c|c|c|c|c|c|}
\hline Gender & Minimum & Maximum & Mean & Median & Mode & Standard deviation \\
\hline Boys & 18.0 & 36.0 & 26.65 & 26.0 & 36.0 & 5.92 \\
\hline Girls & 18.0 & 36.0 & 26.29 & 25.0 & 24.0 & 5.66 \\
\hline
\end{tabular}

Tab. 2. Frequencies by gender and age

\begin{tabular}{|c|c|c|c|c|c|c|c|c|c|}
\hline Scale & All & Boys & $\mathbf{1 8 - 2 3}$ & $\mathbf{2 4 - 3 0}$ & $\mathbf{3 1 - 3 6}$ & Girls & $\mathbf{1 8 - 2 3}$ & $\mathbf{2 4 - 3 0}$ & $\mathbf{3 1 - 3 6}$ \\
\hline Negativity (NEG) & 0.70 & 0.67 & 0.63 & 0.60 & 0.76 & 0.72 & 0.73 & 0.65 & 0.77 \\
\hline Surgency (SUR) & 0.65 & 0.63 & 0.47 & 0.69 & 0.68 & 0.67 & 0.63 & 0.61 & 0.75 \\
\hline $\begin{array}{c}\text { Effortful Control } \\
\text { (EFFC) }\end{array}$ & 0.71 & 0.69 & 0.60 & 0.75 & 0.71 & 0.72 & 0.72 & 0.72 & 0.63 \\
\hline
\end{tabular}




\begin{tabular}{|c|c|c|c|c|c|}
\hline \multirow[t]{2}{*}{ Factor name } & \multirow[t]{2}{*}{ Items } & \multicolumn{3}{|c|}{ Range of factor loading } & \multirow{2}{*}{$\begin{array}{c}\text { Number of items (total } \\
\text { number of items in a scale) }\end{array}$} \\
\hline & & 1 & 2 & 3 & \\
\hline \multirow{11}{*}{$\begin{array}{l}\text { Negativity } \\
\text { (NEG) }\end{array}$} & 2 Frustration & & 0.48 & & \multirow[t]{11}{*}{$11(12)$} \\
\hline & 10 Motor Activation & & 0.40 & & \\
\hline & 16 Discomfort & & 0.40 & & \\
\hline & 17 Discomfort & & 0.46 & & \\
\hline & 19 Fear & & 0.56 & & \\
\hline & 22 Sadness & & 0.65 & & \\
\hline & 23 Sadness & & 0.60 & & \\
\hline & 26 Frustration & & 0.70 & & \\
\hline & 32 Fear & & 0.62 & & \\
\hline & 33 Soothability & & 0.60 & & \\
\hline & 34 Soothability & & 0.57 & & \\
\hline \multirow{9}{*}{$\begin{array}{l}\text { Surgency } \\
\text { (SUR) }\end{array}$} & 3 Sociability & 0.40 & & 0.44 & \multirow[t]{9}{*}{$9(12)$} \\
\hline & 4 Impulsivity & & & 0.41 & \\
\hline & 6 High-intensity Pleasure & & & 0.37 & \\
\hline & 9 Positive Anticipation & & & 0.48 & \\
\hline & 13 Impulsivity & & & 0.40 & \\
\hline & 18 Activity Level/Energy & & & 0.36 & \\
\hline & 20 Activity Level/Energy & & & 0.53 & \\
\hline & 30 Sociability & 0.33 & & 0.54 & \\
\hline & 36 Sociability & 0.34 & & 0.62 & \\
\hline \multirow{11}{*}{$\begin{array}{l}\text { Effortful Control } \\
\text { (EFFC) }\end{array}$} & 5 Low-intensity Pleasure & 0.41 & & & \multirow[t]{11}{*}{$11(12)$} \\
\hline & 7 Attentional Focusing & 0.41 & & & \\
\hline & 8 Attentional Shifting & 0.42 & & & \\
\hline & 12 Cuddliness & 0.38 & & & \\
\hline & 15 Attentional Shifting & 0.43 & & & \\
\hline & 21 Inhibitory Control & 0.43 & 0.41 & & \\
\hline & 27 Inhibitory Control & 0.53 & 0.33 & & \\
\hline & 28 Low-intensity Pleasure & 0.58 & & & \\
\hline & 29 Cuddliness & 0.53 & & & \\
\hline & 31 Inhibitory Control & 0.48 & & & \\
\hline & 35 Attentional Shifting & 0.54 & & & \\
\hline
\end{tabular}

Tab. 4. Extracted factors and level of factor loading

In the Negativity scale, there was no statistically significant difference in gender and age interaction, $F(2,703)=1.49$, $p=0.23$ but also no significant difference in age $F(2,703)=1.99, p=0.14$ and gender $F(1,703)=1.91, p=0.17$.
This was confirmed by the Tukey post hoc tests. In the case of the Surgency scale, there was no statistically significant difference in sex and age interaction, $F(2,703)=1.67, p=0.19$, but also no significant difference in sex versus $F(1,703)=0.02, p=0.91$.

\begin{tabular}{|l|c|c|c|c|c|c|c|c|}
\hline & \multicolumn{3}{|c|}{ Boys } & \multicolumn{3}{c|}{ Girls } \\
\hline \multicolumn{1}{|c|}{ Scale } & $\mathbf{1 8 - 2 3}$ & $\mathbf{2 4 - 3 0}$ & $\mathbf{3 1 - 3 6}$ & Total & $\mathbf{1 8 - 2 3}$ & $\mathbf{2 4 - 3 0}$ & $\mathbf{3 1 - 3 6}$ & Total \\
\hline Negativity (NEG) & & & & & & & & \\
M & 3.08 & 3.18 & 3.20 & 3.15 & 3.19 & 3.36 & 3.19 & 3.26 \\
SD & 0.67 & 0.71 & 0.84 & 0.73 & 0.82 & 0.73 & 0.89 & 0.80 \\
Me & 3.00 & 3.13 & 3.21 & 3.10 & 3.08 & 3.33 & 3.08 & 3.17 \\
\hline Surgency (SUR) & & & & & & & & \\
M & 4.95 & 5.02 & 5.09 & 5.02 & 4.86 & 4.99 & 5.21 & 4.99 \\
SD & 0.63 & 0.71 & 0.68 & 0.67 & 0.71 & 0.63 & 0.73 & 0.69 \\
Me & 5.08 & 5.08 & 5.17 & 5.08 & 4.91 & 5.08 & 5.33 & 5.08 \\
\hline Effortful control & & & & & & & & \\
(EFFC) & 4.47 & 4.63 & 4.71 & 4.0 & 4.59 & 4.67 & 5.08 & 4.75 \\
M & 0.64 & 0.73 & 0.77 & 0.72 & 0.76 & 0.74 & 0.69 & 0.76 \\
SD & 4.50 & 4.70 & 4.75 & 4.66 & 4.58 & 4.67 & 5.04 & 4.45 \\
Me & & & & & & \\
\hline
\end{tabular}

Tab. 5. Descriptive statistics for scales scores in boys and girls 
However, there was a statistically significant difference in relation to age, $F(2,703)=7.84, p=0.00$. This fact was confirmed by the result of the Tukey post hoc tests, which showed differences in the age at the level of significance of 0.01, resp. 0.05. In the Effortful Control scale, there was no statistically significant difference in sex and age interaction, $F(2,703)=2.79$, $p=0.62$. But statistics showed a significant difference depending on age, $F(2,703)=15.53, p=0.00$, and depending on sex, $F(1,703)=11.57, p=0.00$. This fact was confirmed by the Tukey post hoc tests, which showed a difference of 0.01 in significance.

\section{DISCUSSION}

The main aim of the study was to verify whether the adapted version of the ECBQ VSF questionnaire is applicable to the Czech population in accordance with the original version. The number of the target group children $(N=709)$, according to the data as stated by Hague (2003), appears suitable and can be considered representative.

The reliability of the test was verified using Cronbach's alpha in accordance with the original questionnaire (Putnam et al., 2010). The values of the Cronbach's alpha scales are, apart from the Surgency scale, comparable to those of the original version.

The values of the Cronbach's alpha scales are comparable to those of the original version, excluding the Surgency scale. For the Surgency scale, the value (alpha $=0.65)$ is lower than the original version (alpha $=0.72$ ) but is still acceptable. Because of the planned use of the questionnaire in practice, reliability was determined separately for each gender and age category. The value of Cronbach's alpha was generally lower for the Surgency scale. In boys aged 18-23 months, it did not reach the limit of acceptability. Further analysis revealed that it was precisely on this scale that three items had to be excluded (High-intensity Pleasure, Activity Level/Energy, Positive Anticipation). Excluding these items, Cronbach's alpha, which did not differ significantly from the original values, was again counted down to the 18-23-month age group for boys. Cronbach's alpha was at an acceptable level (alpha $=0.68)$. A more detailed analysis showed that respondents do not show a normal distribution in these response items. We are currently considering collecting additional data for boys of this age group and making a new analysis to decide what to do with the items. The factor analysis allows the creation of factors which are loaded with certain items. Here it concerned the verification of the items which were given; if - even after the adaption of the questionnaire - they create the corresponding scales and the individual items are fundamental to the particular scale. The data in Tab. 4 shows that five items emerged, however, they did not load any factor (Shyness, High-Intensity Pleasure, Activity Level/Energy, Positive Anticipation, and Attentional Focusing). The responses to the five items which fed none of the three extracted factors were analysed further. items presented an abnormal distribution. More than half of the respondents answered that the given phenomenon was either frequent or, conversely, did not occur at all. These items will be subjected to the further research; we plan further interviews with cooperating mothers. The factor analysis thus proved that the division of items into particular scales (Putnam et al., 2006) is also valid in the Czech version. Because of the expected use of the mentioned questionnaire, the difference between age and gender was investigated. The results show significantly higher scores for girls than boys on the Overall Effortful Control scale. Other significant differences are in Surgency and Effortful Control scale in relation to age. It can be said that the score increases with age in a given scale. Putnam et al. (2006) achieved the same results. Similar conclusions about gender and age. However, they have not shown any significant influence of gender or age on the Negativity scale.

It is possible to find in the literature that there are differences between the temperaments of girls and boys. For example, Goldsmith (1996) describes the differences between the gender of toddlers in his sample of children. Gender differences in the affection of male infants' activity have been described (Campbell and Eaton, 1999), but for example, in 6-7-year-old children, Ahadi et al. (1993) found differences in the Control and Low-Intensity Inhibitors parameters using mothers' reports. Pleasure and Perceptual Sensitivity came out in a favorite of American girls, while the opposite was the case in the Chinese sample. It can, therefore, be expected that there will be differences between the sexes in different national groups.

We need to emphasise that no norms are established; they are created in standardised tools, although the stated results, together with the adaptation of the questionnaire described here, lead towards them. The authors of the questionnaire took a comparable approach (Gartstein and Rothbart, 2003). Here we do not give values for the lower and upper quartiles, so the data is not interpreted as norms. These values will be offered to authorised experts.

\section{CONCLUSIONS}

These results show that the adjusted questionnaire's reliability, the corresponding number of scales, and the items that load the scales are as good as in the original tool. The difference between boys and girls has not been proven, except for three exceptions. The results of the study showed that the temperament survey questionnaire is adapted to the Czech population and can be used in accordance with the rules and focus of the original questionnaire.

\section{APPLICATION TO PRACTICE}

The final Czech version of the ECBQ VSF questionnaire is available on the website of the original team of authors. The outcomes obtained will be offered to paediatricians, neonatologists, and psychologists who deal with the 
research issues focused on the temperament of children in this age category. Interest from experts who work with the parents of handicapped children is also expected. A side benefit was the feedback from the parents who filled in the questionnaire during the main research, stating that they welcomed the "instructions" on how to observe their child and for what and where to seek possibilities for activation and stimulation.

(https://research.bowdoin.edu/rothbart-temperamentquestionnaires/instrument-descriptions/the-early-childhood-behavior-questionnaire/)

\section{Conflict of interest}

Research activities were conducted in accordance with the American Psychological Association code of ethics, and no conflicts of interest were at work.

\section{Funding/Support and role of the sponsor}

A published study was supported by the grant agency UP CMTF_2018_003; IGA_PdF_2018_008.

\section{References}

Ahadi SA, Rothbart MK, Ye R: Children's temperament in the US and China: similarities and differences. Eur J Pers 1993; 7: 359-378.

Baer J, Schreck M, Althoff RR et al.: Child temperament, maternal parenting behavior, and child social functioning. J Child Fam Stud 2015; 24: 1152-1162.

Barbu S, Cabanes G, Le Maner-Idrissi G: Boys and girls on the playground: sex differences in social development are not stable across early childhood. PLoS One 2011; 6: e16407.

Blatný M (ed.): Psychologie osobnosti: hlavní témata, současné př́stupy. Grada Publishing, Praha 2010.

Buss AH: The EAS theory of temperament. In: Strelau J, Angleitner A (eds.): Explorations in Temperament: International Perspectives on Theory and Measurement. Plenum Press, New York, NY 1991: 43-60.

Campbell DW, Eaton WO: Sex differences in the activity level of infants. Infant Child Dev 1999; 8: 1-17.

Gartstein MA, Rothbart MK: Studying infant temperament via the revised Infant Behavior Questionnaire. Infant Behav Dev 2003; 26: 64-86.

Goldsmith HH: Studying temperament via construction of the Toddler Behavior Assessment Questionnaire. Child Dev 1996; 67: 218-235.
Hague P: Průzkum trhu: příprava, výběr metod, provedení, interpretace výsledků. Computer Press, Brno 2003.

Kagan J: Temperamental contributions to social behavior. Am Psychol 1989; 44: 668-674.

Klein VC, Putnam SP, Linhares MBM: Assessment of temperament in children: translation of instruments to Portuguese (Brazil) language. R Interam Psicol 2009; 43: 552-557.

Penela EC, Walker OL, Degnan KA et al.: Early behavioral inhibition and emotion regulation: pathways toward social competence in middle childhood. Child Dev 2015; 86: 1227-1240.

Potměšil $M$, Potměšilová $P$ : Temperament in early childhood and its description using IBQR VSF. Čes-slov Pediat 2017; 72: 240-244.

Putnam SP, Gartstein MA, Rothbart MK: Measurement of finegrained aspects of toddler temperament: the Early Childhood Behavior Questionnaire. Infant Behav Dev 2006; 29: 386-401.

Putnam SP, Helbig AL, Gartstein MA et al.: Development and assessment of short and very short forms of the Infant Behavior Questionnaire-Revised. J Pers Assess 2014; 96: 445-458.

Putnam SP, Jacobs JF, Gartstein MA et al.: Development and assessment of short and very short forms of the Early Childhood Behavior Questionnaire. Poster presented at the annual International Conference on Infant Studies, Baltimore, MD 2010.

Rothbart MK: Early Childhood Behavior Questionnaire - Very Short Form. 2009. Available from: https://research.bowdoin.edu/rothbart-temperament-questionnaires/instrument-descriptions/theearly-childhood-behavior-questionnaire/ [cited 15 November 2018].

Rothbart MK: Temperament, development, and personality. Curr Dir Psychol Sci 2007; 16: 207-212.

Rothbart MK, Hwang J: Temperament and the development of competence and motivation. In: Elliot AJ, Dweck CS (eds.): Handbook of Competence and Motivation. Guilford Publications, New York, NY 2005: 167-184.

Rothbart MK, Ahadi SA, Hershey KL et al.: Investigations of temperament at three to seven years: the Children's Behavior Questionnaire. Child Dev 2001; 72: 1394-1408.

Rubin DH, Crehan ET, Althoff RR et al.: Temperamental characteristics of withdrawn behavior problems in children. Child Psychiatry Hum Dev 2017; 48: 478-484.

Shiner RL, Buss KA, McClowry SG et al.: What is temperament now? Assessing progress in temperament research on the twenty-fifth anniversary of Goldsmith et al. Child Dev Perspect 2012; 6: 436-444.

Standards for Educational and Psychological Testing. American Educational Research Association, American Psychological Association, National Council on Measurement in Education, Joint Committee on Standards for Educational and Psychological Testing (U.S.), 2014.

Ullsperger JM, Nigg JT, Nikolas MA: Does child temperament play a role in the association between parenting practices and child attention deficit/hyperactivity disorder? J Abnorm Child Psychol 2016; 44: 167-178. 